\title{
Linguagem, espaço e nação: um mapeamento das identidades multigeográficas do protagonista imigrante \\ Cecily Raynor ${ }^{1}$
}

\begin{abstract}
Se os imigrantes inquietam tanto (e muitas vezes de maneira tão abstrata) as pessoas instaladas, talvez seja, em primeiro lugar, porque eles lhes demonstram a relatividade das certezas inscritas no solo.
\end{abstract}

Marc Augé

Examinando a literatura contemporânea sob o ponto de vista da migração, temos um ponto de partida adequado para uma avaliação mais extensa da transnacionalidade. Isso é verdade devido à sua dualidade inerente: protagonistas migrantes frequentemente vacilam, tanto concreta quanto figurativamente, entre diversos espaços nacionais. Ao considerar a íntima união entre o espaço e o pertencimento, essas narrativas liberam, muitas vezes, geografias instáveis, como Marc Augé (1994) observa, permitindo que os leitores percebam os cruzamentos entre o nacional e o transnacional, entre o global e o local na vida contemporânea. Narrativas sobre a migração expõem a artificialidade das fronteiras espaciais, ampliando e interrompendo noções fixas de tempo e espaço, em um intrincado processo de negociação e apropriação cultural.

Na literatura brasileira contemporânea, tais tendências relacionadas à escrita do protagonista migrante encontram eco nas obras de uma variedade de autores, incluindo Milton Hatoum (1990), Adriana Lisboa (2007, 2010), Daniel Galera (2008), Bernardo Carvalho (2009) e Chico Buarque (2003). É importante esclarecer que, enquanto eu recorto este subconjunto da literatura, a fim de abordar a noção de transnacionalidade literária, essas narrativas, ficcionais ou não, são essenciais para a escritura da nação. Esta é uma afirmação importante, considerando a resistência histórica das vozes dos imigrantes, que formam parte das histórias nacionais, como Jeffrey Lesser comenta: "Muitas vezes os estudiosos retratam os imigrantes como 'estranhos' e, portanto, fora da experiência nacional. Muitos intelectuais latino-

\footnotetext{
${ }^{1}$ Professora de estudos latino-americanos da Universidade de McGill, Montreal, Quebec, Canadá. E-mail: cecily.raynor@gmail.com
} 
americanos encaram os imigrantes e seus descendentes da mesma maneira" (Lesser, 2013, p. 197, tradução nossa).

Essas histórias não são apenas um componente fundamental das literaturas nacionais, elas também nos ajudam a compreender a estratificação complexa de imaginários nacionais, às vezes espelhando agendas políticas do Estado em suas representações dos migrantes, como observado por Leonardo Tonus: “Ao longe de sua existência, o imigrante tem sofrido um processo de alegorização [...] que o tem privado de sua capacidade de expressar um conteúdo que não seja aquele concedido pelo olhar autoral: conteúdo nacionalista, cosmopolita, regionalista ou transcultural" (Tonus, 2012, p. 94). Essas representações podem ser reveladoras a esse respeito, ajudando os leitores a entender o terreno complexo da "identidade nacional", muitas vezes, construído a partir de elementos heterogêneos e, até mesmo, contraditórios.

Neste artigo, analiso duas obras que narram a migração a partir de ângulos distintos: Estive em Lisboa e lembrei de você, de Luiz Ruffato (2009), um romance contemporâneo centrado na história de um migrante mineiro que vai para Lisboa, e Mar paraguayo, de Wilson Bueno (1992), que conta a história de uma prostituta paraguaia sem nome que reside em Guaratuba. Mais especificamente, argumento que os romances de migração com temas contemporâneos desafiam, alongam e/ou interrompem a coesão narrativa do espaço-tempo, obscurecendo, muitas vezes de forma progressiva, as fronteiras entre o nacional e o transnacional. Examino a ideia do espaço tanto no sentido concreto, no âmbito doméstico e o espaço urbano, quanto no sentido metafórico. Neste marco teórico expandido, estendo o argumento espacial ainda mais, postulando que essas narrativas não só transgridem ou transcendem os espaços tangíveis, mas também geram novas ou alternativas possibilidades espaciais a partir das quais podemos observar a construção e a manutenção da identidade. Elas são: i) o(s) espaço(s) fluído(s) da memória; ii) o(s) espaço(s) criado(s) por meio de redes transnacionais/translocais; e iii) o(s) espaço(s) produzido(s) através da linguagem, através de regionalismos, palavras de herança e/ou a invenção de uma linguagem híbrida. Em vez de examinar as obras em ordem cronológica, faço uma análise temática, começando com o conceito da (trans)localidade, central em Estive em Lisboa e lembrei de você.

\section{Os resíduos locais em Estive em Lisboa e lembrei de você}


Duas das limitações teóricas do conceito de transnacionalidade são a ênfase implícita nas fronteiras geopolíticas e a centralidade atribuída ao Estado-nação. Esta ênfase pode ignorar vestígios e repetições locais que existem dentro de espaços globais, em particular no que diz respeito às configurações socioespaciais que surgem no processo de migração. As dinâmicas multifacetadas de poder, inerentes ao movimento nos territórios, são recorrentemente exploradas na literatura contemporânea, diversas vezes contando histórias profundamente locais de protagonistas de várias posições sociais. Os teóricos Tim Oakes e Louisa Schein usam o conceito de translocalidade para deslocar a ênfase de volta para esses espaços locais: "A translocalidade chama a atenção para as formas múltiplas da mobilidade, sem perder de vista a importância de localidades na vida das pessoas" (Oaks e Schein, 2006, p. 1, tradução nossa). Esse marco teórico reconhece que o movimento entre as geografias nem sempre designa uma mudança na posição social. Ele também coloca ênfase na localidade, reiterando a relação entre o espaço e a pertença. Se entendermos o local como pertencente a uma determinada área ou bairro, é claro que ele é relativo e múltiplo, possibilitando a geração de espaços translocais através de redes sociais e do ato de contar histórias entre os migrantes. Eu me aproximo do texto por meio de sua ênfase na localidade, uma forma influente de entender as geografias fluidas da experiência do imigrante, a fim de desconstruir a interação local/global predominante no romance.

Estive em Lisboa e lembrei de você é uma obra calculadamente centrada nos espaços locais e regionais. Isso se observa na linguagem do romance, na sua estrutura narrativa e na representação das ligações entre os protagonistas imigrantes. Em contraste com os cinco volumes panorâmicos do Inferno provisório, que Ruffato publicou de 2005 a 2011, o romance é notavelmente breve, ocupando menos de cem páginas. A obra faz parte da coleção Amores Expressos, da Companhia das Letras, a qual enviou dezesseis escritores a diferentes países para escrever histórias de amor. Embora essa tarefa possa ser interpretada de forma ampla, é curioso notar que a relação mais íntima que existe na obra é, de fato, entre o protagonista, Serginho, e seu cigarro, um vício que não só estrutura a história, mas também vem a ser emblemático na medida em que as experiências locais do personagem continuam a ser vitais para ele no exterior. A primeira parte chama-se "Como parei de fumar" e se 
passa em Cataguases, cidade natal de Ruffato no interior de Minas Gerais, e continua até sua decisão de imigrar para Lisboa na segunda parte do livro, intitulada "Como voltei a fumar". Apesar da clara divisão, Serginho reside em um espaço psicológico no meio desses espaços, entre o Brasil e Portugal, o qual Ruffato enfatiza de uma maneira determinada.

Ruffato articula a fluidez desse "entre-espaço" visivelmente através da linguagem e da estilística da narrativa. Sua experimentação com a linguagem não é um novo recurso nessa obra, mas ocupa muitas de suas obras, como Inferno provisório (2005-2011) e Eles eram muitos cavalos (2001). Este livro apresenta setenta micronarrativas para capturar um único dia em São Paulo em 2001, por meio de táticas como "estilhaços, fragmentos polifônicos [...] ora narrados em primeira, ora em terceira pessoa, ora em discurso direto, ora em indireto, ora em indireto livre, ora em forma de carta, ora em forma de oração" (Levy, 2003, p. 176). A capacidade de capturar a pluralidade e mesmo a cacofonia de vozes e perspectivas, bem como a autenticidade dos próprios relatos, é uma tendência recorrente na obra do autor. Após os epitáfios, o leitor descobre que o texto é baseado em uma série de testemunhos gravados por um trabalhador mineiro que imigra a Lisboa. Ruffato imita a oralidade do testemunho de diversas maneiras, inclusive imitando o ritmo e a cadência de uma história contada em voz alta, com o uso escasso de vírgulas e poucos recuos. Em uma entrevista informal com o autor, eu vim saber que, como muitos aspectos do romance, o testemunho foi fabricado e nunca aconteceu: "Então assim, o que eu fiz foi uma brincadeira com o leitor de propor a ele que aquilo não era uma ficção. Aquilo ali era uma verdade. E como verdade então ele compra essa história de uma maneira diferente de que se não fosse uma verdade, embora no fundo não seja uma verdade" (Ruffato, 2013, informação verbal). ${ }^{2}$ Como Ruffato observa, a leitura inspirada em um testemunho se diferencia dramaticamente de uma narrativa fictícia. Esta revelação é certamente esclarecedora se considerarmos a capacidade da ficção em confundir ou borrar a noção de autenticidade. Também obriga o público leitor a examinar a fabricação de regionalismos, nacionalismos e outros marcadores geográficos, o que nos traz de volta à porosidade

\footnotetext{
${ }^{2}$ As citações do autor reproduzidas neste artigo foram colhidas por meio de entrevista pessoal realizada em 5 de agosto de 2013, em João Pessoa (PB).
} 
do espaço em si. No entanto, em alguns aspectos, é irrelevante que o testemunho seja fictício. Voltando à posição de um leitor não privilegiado, a transnacionalidade do texto não depende da veracidade do testemunho, mas da história e dos padrões linguísticos fundamentados no português mineiro que o protagonista leva para Portugal.

A utilização de regionalismos é um aspecto abrangente no livro, começando com o título; em vez de Estive em Lisboa e me lembrei de você, Ruffato opta pela remoção do pronome reflexivo. Os indicadores de localidade linguística não são ambíguos ou deixados a critério dos leitores; em vez disso, Ruffato os destaca com o uso de itálico, a fim de sublinhar as palavras que fazem parte do léxico mineiro e suas expressões, e usa palavras em negrito para chamar atenção às palavras assimiladas em Lisboa: "Lisboa cheira sardinha no calor e castanha assada no frio, descobri isso revirando a cidade de cabeça-pra-baixo, de metro, de elétrico, de autocarro, de comboio, de a-pé" (2009, p. 67, grifos no original). Os geossemanticistas Ronald e Suzanne Scollon nos avisam que: "Os idiomas indexam o mundo" e que "muito do que entendemos depende de onde exatamente nós e nosso idioma se localizam no mundo" (Scollon e Scollon, 2003, p. 13, tradução nossa). Dessa forma, as palavras em itálico não só revelam a origem de Serginho, operando como uma geografia portátil, mas também marcam o território (espacial e simbólico) de sua identidade progressivamente multifacetada. Sua fala revela origens, limites e possibilidades. Essa tática deliberada de destacar regionalismos é valiosa na medida em que chama a atenção para a ligação flexível entre a língua, o espaço e a identidade. A primeira parte da obra se caracteriza pelos regionalismos mineiros em itálico, e a segunda por uma mistura de palavras em negrito para destacar o português continental, misturando palavras regionais. Assim, os leitores não podem deixar de notar o fluxo e o refluxo entre o local e o transnacional. Alcides Villaça aponta que essa tática permite também um jogo linguístico, sem diminuir a experiência dolorosa e complexa de imigração em que o hibridismo é tanto um fardo como uma maldição:

Há mesmo a busca da plenitude de uma oralidade, marcada a princípio pelos acentos de um falar mineiro, em que ressoam timbres de quem bem "proseia", e depois marcada por incorporações do falar lisboeta, tudo resultando num estatuto 
híbrido e divertido, que nem por isso apaga as marcas da penosa condição do imigrante (Villaça, 2009, s.p.).

Além do uso do itálico, a primeira metade do romance inclui uma variedade de referências locais com coordenadas geográficas específicas, como de restaurantes e bares, através de nomes de ruas e bairros que formam parte da experiência local de Serginho: "Bairros da margem esquerda do rio Pomba, Vila Resende, Granjaria, Leonardo, BNH, Vila Domingos Lopes, Vila Reis, Barridê, Tomé, Matadouro, Ana Carrara" (2009, p. 32). Esse mapeamento é fundamental para a concepção do texto como "testemunho", permitindo-lhe ganhar mais legitimidade em sua prolongada "brincadeira" com os leitores:

Então, isso é uma coisa assim, que é você criar uma noção de realidade, que, a partir de elementos concretos, mostra uma ilusão... Então assim, esses signos, eles são interessantes pra você poder questionar a própria questão da realidade, o que que é real e o que que não é, né? Ele [o mapeamento] transforma aquilo em real, mas é falso, porque é um falso real, porque o real que não existe! Como pode existir sem Serginho? (Ruffato, 2013, informação verbal).

É importante ressaltar que o mapeamento de Ruffato, ou, como ele mesmo diz, a sua transformação de ficção em realidade, excede o espaço geográfico de Cataguases, estendendo-se por Minas Gerais. Essa tática não só lhe permite ganhar autenticidade como cartógrafo do testemunho (fictício), mas também estende e expande a fundação geográfica da história.

De acordo com o enfoque no local, é importante observar que Serginho afirma-se como mineiro e não apenas como brasileiro ou latinoamericano. Na segunda parte, ele é convidado a dizer algo em "brasileiro": "Enuncie alguma coisa, ó brasileiro, quero ouvir a música da tua fala" (2009, p. 50). Curiosamente, Serginho opta por responder com um regionalismo, confundindo e agradando o ouvinte português, que a partir desse momento lhe solicita que fale com seu "acento", proclamando: “Estes brasileiros!” (2009, p. 51). Essa interação não só enfatiza a geografia da língua, mas também captura a diversidade dos imigrantes, muitos dos quais se agrupam por sua origem nacional. Nossa leitura da localidade pode ser enriquecida pela diferenciação que Michel de Certeau faz entre a ideia fixa do lugar e a plasticidade do espaço: "O espaço é um lugar praticado. Assim a rua geometricamente 
definida por um urbanismo é transformada em espaço pelos pedestres" (Certeau, 1984, p. 201-202). Segundo esse marco teórico, a linguagem pode ser concebida como espaço próprio, se mudando e se transformando para refletir a geografia, o tempo e a identidade. Nesta sequência e em inúmeras outras, a linguagem serve como sua própria espacialidade móvel, permitindo que os protagonistas se movam e constituam sua permanência local de uma vez. O idioma também conecta os protagonistas transnacionais porque compartilham um imaginário linguístico. Os leitores podem observar isso claramente quando outra imigrante brasileira identifica Serginho como mineiro segundo sua fala: "[...] Você é mineiro [...] só mineiro fala 'Aqui'” (2009, p. 61). Depois, numa interação com outro imigrante, Rodolfo, Serginho pergunta: "Você é brasileiro? confirmou, e, satisfeito, eu [Serginho] disse, 'Puxa vida, que bom encontrar alguém que fala a mesma língua da gente'" (2009, p. 46). Ambos os comentários revelam a relação íntima entre a localidade e o idioma. O segundo não é só divertido porque insinua que o português continental é tão diferente do português brasileiro que pode ser outra língua, mas também porque chama a atenção para as formas pelas quais o idioma pode unir um grupo de imigrantes desterritorializados e sem documentos.

O tratamento do tempo é também enraizado no local. Como anteriormente mencionado, a história não é apenas estruturada pelo ato de fumar, o vício torna-se uma metáfora para os resíduos de memória pessoal, retornando a história para Cataguases. A relação entre Serginho e o ato de fumar abrange seis anos e meio, um prazo revelado na linha final do trabalho: "E foi assim que, depois de seis anos e meio, pouco mais ou menos, entrei numa tabacaria, pedi um maço de SG, um isqueiro, tirei um cigarro, acendi e voltei a fumar" (2009, p. 83). O ato de fumar é constantemente retratado como um assunto profundamente local, tanto temporalmente, quando ele deixa de fumar, ("O primeiro do Abril"), quanto espacialmente, ("Saí do prédio [do doutor Fernando], atravessei a praça Rui Barbosa, aviei a receita na Drogaria do Povo") (2009, p. 16). Quando Serginho contempla o ato de voltar a fumar em Lisboa, ele não só se lembra do doutor Fernando, mas de toda uma população de protagonistas locais que ficaria decepcionada se ele o fizesse: "Quê isso, Serginho! Vai decepcionar agora as milhares de pessoas que acompanham há anos seus hercúleos esforços?" (2009, p. 44). Assim, o ato de fumar vai além de sua associação com uma 
configuração espaçotemporal específica, está ligada a uma comunidade local inteira que Serginho leva para Portugal na sua memória.

O entrelaçamento e a interconectividade do local são temas explorados no trabalho de Ulrike Freitag e Achim von Oppen, que entendem a translocalidade como uma forma de destacar a mélange da vida contemporânea, um conceito capaz de "quebrar as limitações de historiografias nacionalistas, bem como uma metanarrativa histórica" (Freitag e Von Oppen, 2010, p. 2). A desconstrução do espaço em textos transnacionais ilustra precisamente o fluxo e a fusão entre o local e o transnacional, o que nos permite afastar-nos da nação como um modelo literário abrangente e examinar a linguagem, a memória e os movimentos físicos desde um ponto de vista mais complexo. Ao contrário dos espaços domésticos tão proeminentes em muitos outros romances sobre a imigração, incluindo Relato de um certo oriente (Hatoum, 1990), Rakushisha (Lisboa, 2007) e Nihonjin (2011), em Estive em Lisboa... a cidade é a plataforma para a tecelagem do passado e do presente, do local e do transnacional. Ao considerar a transitoriedade dos imigrantes mais amplamente, o foco no espaço público é lógico, dado que os imigrantes são, muitas vezes, arrancados de seus lares e nunca chegam a estabelecer espaços domésticos permanentes no exterior.

O exemplo mais sobressaliente para ilustrar essa tecelagem do passado e do presente no espaço urbano é um encontro entre Serginho e Sheila no sábado, que concluirá minha análise do texto. Os dois começam seu dia em uma "tasca brasileira" no centro de Lisboa, onde Sheila começa a contar sua história pessoal usando marcadores espaciais locais. Ela conta sobre os "tormentos de garota nascida em Maurilândia" e depois da sua transição para uma fazenda de soja "em Riverlândia, distrito de Rio Verde" (2009, p. 62-63). Depois, na escola, fez uma excursão à capital de Goiás, Goiânia, onde realizou um projeto "sobre os monumentos da cidade, ao Bandeirante e às Três Raças" (2009, p. 62-63). Em Goiânia, ela é atraída para a prostituição por um grupo de amigos que viaja para a Espanha. Semelhante à narrativa de Serginho, a história da Sheila está enraizada em uma série fragmentada de referências locais. Ela consegue deslocar e prolongar o tempo da narrativa através de lembranças extensas, e sua biografia é sumamente móvel enquanto ela passa de Goiás para as ruas de Lisboa: “[...] Rua Augusta, rua do Ouro, rua da Prata, rua do Carmo, rua Garrett [...] avenida da Liberdade" (2009, p. 67). Seu percurso espacial acaba nas 
ruas da cidade, onde ela encontra barreiras e bloqueios por causa de sua classe social, seu status como imigrante e sua profissão: "Onde entrava, tratavam ela mal, aos chutes e pontapés, como se portasse sida, ou lepra" (2009, p. 67, grifos no original). Nesta citação, o uso do negrito para indicar o léxico continental reflete o espaço dividido em que os protagonistas imigrantes moram e reforça a ideia do espaço como uma construção social. Apesar de sua capacidade de se mover do Brasil para Lisboa, a experiência espacial de Sheila é extremamente restrita, reiterando que o domínio transnacional não se experimenta de forma homogênea e é profundamente ligado à posição social e ao gênero. Em vez de um espaço libertador, o terreno transnacional chega a ser restringido à sua própria maneira, ditada, em última instância, por seus próprios códigos de poder e barreiras simbólicas e reais. Depois disso, a sequência retorna ao presente, Sheila e Serginho navegam a cidade:

Com ela de-guia, visitamos um monte de sítios bestiais, o Castelo de São Jorge, o Elevador de Santa Justa, Belém (para comer pastel), o Padrão dos Descobrimentos e o Aquário, na estação Oriente, um negócio onde o sujeito enlabirinta em um nunca-acabar de peixe, uns baitas de tubarões e arraias, e outros, bostinhas de nada, mais parecendo bando de passarinho avoando em-dentro d'água, um troço impressionante, fora a imundice de estrela-domar, ouriço-do-mar, medusa etc., e a geladeira dos pinguins giras e a piscina das lontras exibidas, mas o mais importante mesmo foi andar no teleférico (2009, p. 67, grifos no original).

Seu percurso urbano é tanto experiencial como sensorial, o que se vê quando os dois comem o bolo e observam a vida marinha no aquário. Diferentemente dos espaços confinados que normalmente ocupam, Serginho está ficando em um hotel econômico em Lisboa e trabalha em um café, e Sheila faz um percurso limitado nas ruas de Lisboa no seu trabalho como prostituta. Essa passagem é notavelmente aberta, expondo as possibilidades espaciais, pois o espaço urbano transnacional é retratado como um lugar de lazer e diversão, animado pelo trânsito de pessoas e suas atividades. Este tratamento se diferencia muito da discriminação e da exclusão social que tipicamente caracterizam sua estadia na cidade. No entanto, como acontece com frequência no romance, Lisboa é continuamente interrompida por outros tempos e outros lugares. Enquanto a sequência avança, Serginho é levado de 
volta para o território escorregadio da memória, transportado para uma viagem que fez quando criança, pela escola, para o Rio de Janeiro:

Lembrei da vez que fui no bondinho do Pão-de-Açúcar emcriança, excursão do primeiro colegial da Escola Estadual Professor Quaresma, um deslumbre, o Rio de Janeiro, a baía da Guanabara, o Cristo Redentor, as praias, a ventania, a tonteira [...] (2009, p. 68).

Essas lembranças são sumamente afetivas: Serginho lembra-se da sua pobre mãe que repara sua mochila depois da viagem, um objeto que acaba no lixo "num sábado de faxina da dona Zizinha" (2009, p. 68). Há uma sensação incessante nessa sequência que provoca a impressão de que o passado é presente e inevitável ao mesmo tempo. Lisboa, a "magnífica", que aparece no epitáfio do romance, se converte em um lugar para lembranças profundas e específicas. Parece também que a narrativa compartilhada entre os dois desperta uma certa fluidez geográfica entre o que era e o que é, entre Brasil e Lisboa, o que complica e estende os parâmetros da narrativa.

A partir desse momento, a história volta para o presente, para o "Parque das Naçōes", onde Serginho e Sheila aproveitam o sol da tarde. No único momento de intimidade entre o par desterritorializado, os dois entram em um café local, seu destino final. Nesse contexto, suas narrativas mudam tanto temporalmente quanto geograficamente para $o$ Brasil pela última vez. Sheila confessa seu desejo de "juntar muito dinheiro" para poder "aparecer em Riverlândia por-cima-da-carne-seca, engranada, mandando e desmandando" (2009, p. 69). Sua confissão muda a narrativa geograficamente para onde começou, fazendo um círculo no percurso para chegar a Goiás. No entanto, nesse caso, ela fala sobre um futuro incerto e idealizado, em vez de um passado vivido. Por último, a sequência fecha no mesmo território desestabilizado que tipifica o trabalho em geral. Sheila foge do café e abandona Serginho numa posição de vulnerabilidade renovada, um imigrante sozinho em um café em uma cidade que não é sua, sem reconhecimento legal. Juntos, os dois permanecem presos em uma configuração espaçotemporal circular, entre o passado e o futuro, desejando retirarem-se para um Brasil imaginado. No entanto, o Brasil que eles imaginam é instável também, encravado entre o que foi e o que poderia ser. Nesse sentido, os três pontos temporais manifestados no romance, o passado, o presente e o futuro, são 
desprovidos de base sólida, esteticamente refletindo a instabilidade inerente à experiência do imigrante.

Em sua experiência flutuante e imigratória, as relações entre Serginho e seus compatriotas brasileiros nos fornecem consistência e solidariedade provisórias. É possível observar isso quando se atenta para as ligações transnacionais mais significativas de Serginho: não é em sua interação com africanos lusófonos, com o garçom ucraniano ou com os árabes que ele encontra em uma central de atendimento que ele se sente bem, e sim com Sheila e com Rodolfo, dois imigrantes brasileiros. No final da narrativa, Serginho e Rodolfo fazem um passeio a pé por Lisboa e discutem suas experiências de deslocamento, discriminação e nostalgia: "Nós estamos lascados, Serginho, aqui em Portugal não somos nada, 'Nem nome temos', somos os brasileiros, 'E o que a gente é no Brasil?' nada também, somos os outros" (Ruffato, 2009, p. 78).

Esse comentário sobre a realidade do imigrante brasileiro em Lisboa é sombrio, mas também revelador. Mais uma vez, a imigração para Lisboa não altera sua posição social. Em muitos aspectos, ela aumenta a discriminação que os dois enfrentam por serem pobres, estrangeiros e ilegais. Marco Antonio Rodrigues argumenta que existe uma "mobilidade precária" no romance que "viabiliza, a princípio, só a passagem de ida, não guarda relação direta com mobilidade social" (Rodrigues, 2009, p. 190). Contudo, gostaria de afirmar que há uma certa camaradagem que ajuda a estabilizar a existência desses protagonistas transnacionais. Enquanto Rodolfo e Serginho podem não ser nada para os portugueses, eles formam parte de uma entidade social própria dentro do subconjunto dos "outros". Dessa forma, a alteridade é um conceito indenitário, bem como espacial, geográfico e temporal. Os imigrantes são empurrados fisicamente para as margens da cidade e, por isso, obrigados a viver no entre-espaço da memória. Os teóricos que tratam o assunto da transnacionalidade argumentam que as ligações entre imigrantes proporcionam um sentido de estabilidade dentro da mobilidade da imigração, uma suposição apoiada na literatura migratória (Brickell e Datta, 2011).

Refletindo a fugacidade da estadia de Serginho em Lisboa, em geral, as ligações pessoais que ele estabelece acabam sendo efêmeras. Sheila desaparece no mundo obscuro dos imigrantes em Lisboa depois de vender seus passaportes, já Serginho estabelece uma residência separada, enquanto mantém contato limitado com Rodolfo. Qualquer 
sensação de comunidade estabelecida no romance torna-se mais um apego à terra, uma âncora temporária dentro de um mar de dissociação. $\mathrm{O}$ romance termina com Serginho retornando ao vício de fumar: ele entra em uma loja para comprar tabaco, o que remete o leitor ao sentimento de derrota. A cena final não deixa os leitores saberem o futuro de Serginho, mas deixa-os com expectativas e suposições sombrias. Ao mesmo tempo, a capacidade de Serginho de permanecer fiel à sua identidade mineira, na fala, converte o ato de fumar quase em um desafio, um ceder ao desejo da memória e à força da pátria. A pesar do uso de palavras em português continental, as quais se tornam parte de sua fala, a voz de Serginho é inquestionavelmente e corajosamente mineira, algo que não pode ser extinto. A ideia da linguagem como um acompanhamento na viagem do exiliado, e a língua como um elemento constante no processo de deslocamento, é expressa de forma eloquente e simples pelo argentino Juan Gelman (1986) no poema "O expulsado": "Escreve,/ forçaram-me da minha terra/ caminhei sobre a terra/ deportaram-me da minha língua/ ela me acompanhou."

\section{Geografias, intersecções e linguagem em Mar paraguayo, de Wilson Bueno}

Para expandir a metáfora da linguagem como espacialidade móvel, passo agora para um texto que supera a maioria das obras literárias na experimentação com a linguagem como mapeamento do espaço e do tempo, Mar paraguayo, de Wilson Bueno (1992). Como se nota na obra de Ruffato (2009), o espaço e o tempo da nação são deslocados, reescritos e desvendados no âmbito da linguagem. É importante considerar que a própria concepção de nação se baseia no conceito de linguagens comuns, unindo, assim, a língua aos espaços imaginados da pátria. $\mathrm{Na}$ América Latina, as literaturas nacionais não estão isentas dessa tendência, pois são escritas majoritariamente em espanhol, português e línguas indígenas. No entanto, as realidades multilíngues de uma demografia móvel e heterogênea, a qual abriga historicamente grandes populações de imigrantes, deixaram inevitavelmente sua marca na literatura da região. Na América hispânica, uma variedade grande de textos exibe essa tendência, incluindo En la sangre, de Eugenio Cambaceres (1924 [1887]). Este romance conta a história de um migrante italiano que reside em Buenos Aires no século XIX, e inclui passagens 
em italiano e cocoliche, uma mistura entre italiano e espanhol. No Brasil, o poema estendido O guesa, de Joaquim de Sousândrade (1979 [1871]), incorpora várias línguas, inclusive o inglês. $\mathrm{O}$ autor publicou o poema durante sua estadia prolongada nos Estados Unidos. Passando para os séculos XX e XXI, o uso da linguagem é ainda mais complicado se forem consideradas as zonas de contato transnacionais e o movimento acelerado entre os espaços e os espaços virtuais, que alteram a paisagem linguística da escrita, da leitura e da distribuição de textos. Recentemente, na Conferência Mundial do Escritor, realizada em fevereiro de 2013, em Edimburgo, a escritora turca Sema Kaygusuz confirmou que a relação entre a literatura e a nação era interrompida:

Se a estrutura da literatura nacional pode ser entendida a partir de uma perspectiva de linguagem comum, ocorre-me que nenhuma língua pode ser definida por nacionalidade. Isto é porque a linguagem não pertence apenas às pessoas da mesma raça, mas às comunidades. Além disso, tanto como uma linguagem pode conter repertórios de palavras emprestadas de outras línguas, ela pode funcionar como anfitriã de outros idiomas que se fundem uns aos outros (Kaygusuz, 2013, tradução nossa).

Historicamente, o Brasil sediou uma variedade de línguas híbridas, tornando aparentes essas fusões, misturas e empréstimos. Entre muitos outros exemplos, isso pode ser visto no dialeto alemão-brasileiro Riograndenser Hunsrückisch, falado por uma comunidade no Rio Grande do Sul (Lesser, 2013, p. 39). As zonas de contato contemporâneas estão representadas em vários textos, inclusive em Desterro: memórias em ruínas, de Luis Krausz (2011), que inclui palavras em iídiche e alemão para descrever a migração judaica para São Paulo; e em Mamma, son tanto felice, de Luiz Ruffato (2005), que narra a história de uma comunidade de origem italiana em Minas Gerais.

Mar paraguayo, de Wilson Bueno (1992), é um texto excepcional porque não mistura nem substitui duas ou três línguas, ele vai além, cria um novo sistema linguístico com uma sintaxe própria. Essa língua é uma combinação de espanhol, português - conhecida informalmente como portunhol (ou a fusão de português e espanhol) -, palavras inventadas e guarani. Curiosamente, entre as línguas utilizadas, o guarani é a que mais se destaca, o que alguns críticos veem como uma metáfora para a resistência cultural dos grupos indígenas associados a essa língua (Andermann, 2011). 
Graciela Montaldo comparou o texto a um tipo de poesia, afirmando que ele opera em um espaço intersticial, em vez de em um terceiro espaço:

[...] Entre o paradigma europeu e sua resistência nativista que é mais do que o "terceiro espaço" porque se baseia em intersecção entre as bordas; não se sustenta em uma positividade, mas em uma espécie de utopia, na linguagem que exige constante atualização, recriação e ressignificação, ou seja, que nunca deixa de se estabilizar (Montaldo, 2011, p. 3).

Na introdução à novela, Nestor Perlongher também chama o romance de "imediatamente poético" (Perlongher, 1992, p. 9). "Entre as duas línguas há uma hesitação, uma tensão, uma oscilação permanente, uma é o erro da outra, seu devir possível, incerto e improvável" (Perlongher, 1992, p. 8). Nesta análise gostaria de superar a instabilidade e o lirismo do texto, argumentando que Mar paraguayo de fato amalgama seus idiomas para desestabilizar hierarquias de poder e inaugurar novas geografias, mapeando o movimento da protagonista do Paraguai às praias de Guaratuba, no Paraná, com duas línguas nacionais, o espanhol e o guarani. Como vimos no texto de Ruffato (2009), a língua vem a ter três funções: proporciona um modo de autoafirmação para a protagonista, um espaço para a formação de identidade alternativa, bem como um território para a expressão da memória pessoal.

Mar paraguayo está escrito na primeira pessoa, é uma historia multitemporal e não linear. A narradora conta a história de uma prostituta migrante paraguaia sem nome que chama a si mesma de "la marafona del balneário". Ao contrário do romance de Ruffato (2009), essa obra oferece um léxico em guarani de cinco páginas no final do livro, com as traduções correspondentes em português. Em uma narrativa confessional, a protagonista reflete sobre sua morte, suas doenças ("tasy"), a fugacidade da vida ("tecovembiki"), o divino ("tupa"), o inferno ("añaretamegua"), o sexo ("porenó"), a imaginação ("morangúu"), o amor ("mboraihu") e a literatura ("ñandutirenimbó" - telaraña). Como pano de fundo nessas reflexões amplas, o enredo está ancorado no apelo à inocência da narradora em relação à morte de seu amante masculino, conhecido como "el viejo". Embora não seja muito claro se el viejo é um cliente ou simplesmente um companheiro de longo prazo, a sua morte fornece um fio para o texto, aterrando-o em um momento específico: 
El viejo, que moriria a las siete de la noche, en júnio, mexia-se ainda en la casa e yo podria ouvir, con una nitidez epantosa, sus tosses, sus escarros y escárnios, el viejo, esto traste tan duramente amoroso que me llenô la vida e me puso dama de suerte por puro capricho (Bueno, 1992, p. 56).

La marafona lembra-se dessa morte exaustivamente, criando um rito narrativo, um fluxo e refluxo, que imita os padrões fluidos das marés de Guaratuba. De fato, os padrões e as ondas da água que inspiram o título da obra estão capturados textualmente na estética nebulosa, com longas digressões mnemônicas, e em uma mistura de códigos linguísticos. A vastidão do "mar" funciona como um espaço simbólico e figurativo para o entrecruzamento da linguagem e da junção do passado e do presente, em contraste com a sala fechada em que a narradora conta sua história. Ela fica isolada de qualquer contato humano, sozinha no seu quarto de frente para o mar. A imagem do "mar" é desconcertante, uma vez que o Paraguai é um país sem litoral, cercado por Bolívia, Brasil e Argentina. Com isso em mente, o mar "impossível" do Paraguai apresenta para os leitores imediatamente uma conotação figurativa ao invés de concreta, um cosmos misturado de linguagens e influências culturais.

Enquanto narra a morte de el viejo repetitivamente, a novela percorre os espaços semânticos entre o espanhol (Paraguai), o português (Brasil) e a paisagem indígena, dispersa e transnacional do guarani. Esse terreno linguístico se caracteriza pelas interseções, mas também chama a atenção para as separações, para as faltas e para o estranhamento, refletindo o envolvimento da protagonista com uma comunidade marginal. Ela afirma: "Nasci al fondo del fondo del fondo de mi país - esta hacienda guarani, guarânia e soledad" (Bueno, 1992, p. 16). Semelhante à Sheila de Estive em Lisboa... (Ruffato, 2009), marafona experimenta um ostracismo triplo, que tem como base sua classe social, seu gênero e seu status como imigrante ilegal e prostituta. Essa posição é uma armadilha vista em sua relação com os "outros" da paisagem na praia de Guaratuba. Ela observa-os somente através de sua janela, um enquadramento espacial, "al borde de la ventana enquanto los banhistas, con sus esposas gordotas y sus hijos inquietos, llenos de arena, lambuzados de mar $y$ sorvetes con grandes crostas de caramelo, van por el, distarídos, por el camino" (Bueno, 1992, p. 26). 
A separação material e cultural entre a protagonista e os turistas obesos é ainda mais acentuada no uso de uma linguagem misturada. Embora a maior parte deste trecho seja em espanhol, inclui léxico em português, como "lambuzado", "sorvete", e "crosta", o que interrompe a linearidade semântica. De uma maneira que supera o texto de Ruffato (2009), essa linguagem inventada ajuda na construção de um universo linguístico que é exclusivamente da narradora. Algo particularmente interessante sobre o texto é marafona vacilar entre as línguas do centro e da periferia, complicando o que Gilles Deleuze e Félix Guattari (1986) consideram como a construção de uma literatura menor em um idioma maior, isto é, português ou espanhol no caso. O texto usa por vezes português ou o espanhol de forma monolíngue, mas frequentemente mistura essas línguas, criando um espaço no qual não há predominância de nenhuma delas.

De acordo com essa ideia e retornando à linguagem como um índice do mundo, também é claro que as linguagens sempre são estruturadas por relações de poder. O romance, assim, alinha os níveis de poder das três línguas e suas variações, estabelecendo um código alternativo, separado das hierarquias de uma linguagem, de uma só voz. De uma forma que é impossível em textos monolíngues ou bilíngues, esta obra polifônica articula cruzamentos, ao invés de criar coordenadas fixas, contribuindo, mais uma vez, para a estética fluida do texto, dando uma sensação de movimento transnacional.

Em uma perspectiva técnica, a ortografia do trabalho, sua sintaxe e sua linguagem híbrida e inventada reforçam ainda mais essa interação. Às vezes, a protagonista joga com os sons através da ortografia: “Quiçás, quiçás, quiçás. Chororó, guarará, chororó" (Bueno, 1992, p. 58). Aqui, a palavra espanhola "quizás", não muito comum no português do Brasil, é foneticamente simulada pelo "ç", em vez de um " $z$ ". O trecho também oferece uma referência intertextual à canção latino-americana “Quizás, Quizás, Quizás”, do compositor cubano Osvaldo Farrés. O trabalho apresenta uma gama de imagens do Brasil e da América Latina e faz alusões intertextuais a essa região - incluindo "chororó", uma ave nativa do Brasil, e "Guarará", uma cidade de Minas Gerais. Dada a natureza arbitrária dessas alusões, sua presença parece servir-se mais de uma função fonética e tem um valor representativo, uma vez que mantém uma cadência uniforme em ambas as sílabas e na entonação. Isso reforça ainda mais a qualidade poética, lírica e melódica do texto e 
sua prosa devaneadora que às vezes não tem sentido. É importante ressaltar que marafona brinca com a linguagem quando troca códigos linguísticos, o que está em contraste com a gravidade da morte. No que diz respeito à sintaxe, o trabalho apresenta o uso da gramática portuguesa com léxicos espanhóis e também o contrário: "No voy llorar, no voy me poner toda depranto y soluçante y gelatina en lo travessero" (Bueno, 1992, p. 49). Em outras ocasiões, as duas ortografias são misturadas para criar um amálgama: "San cosas de la imaginación" (Bueno, 1992, p. 51). Neste caso, "san" é um cruzamento de "son", do espanhol, e "são", do português, verbo "ser" conjugado na terceira pessoa do plural. Finalmente, o autor oferece exemplos em que nem o espanhol, nem o português, nem guarani são preservados - palavras com erros ortográficos propositais ou a invenção de novos vocábulos, visto em exemplos como "vierbos" (Bueno, 1992, p. 33).

Ao considerar a estrutura da obra, a caráter testemunhal do texto alinha-o à forma de Estive em Lisboa... (Ruffato, 2009) : “Escribo para que no me rompam dentro las cordas del corazón [...]. Soy mi propria construción e asi me considero la principal culpada por todos los andaimes derruídos de mi projeto esfuerzado [...]" (Bueno, 1992, p. 32-33). No entanto, a escritura de Mar paraguayo vai além de um testemunho, funcionando como uma espécie de confessionário, uma liberação de culpa, uma assunção de responsabilidade. É a voz de marafona, em toda a sua inventividade e fragmentação, que é vital para a formação da verdade pessoal, além de uma afirmação de si, uma declaração de existência. Ela diz: "No hay idiomas aí. Solo la vertigem de la linguagem. Deja-me que exista" (Bueno, 1992, p. 13). Embora marafona não considere sua linguagem híbrida como uma língua oficial, apenas "vertigem" de uma língua, uma metáfora particularmente sensorial, de acordo com a natureza estonteante da narrativa, a frase que se segue é clara quanto à sua intenção: "Deja-me que exista."

Empurrada para a periferia da sociedade, sua escrita torna-se análoga à ocupação do espaço e à criação de suas próprias margens linguísticas, representacionais, culturais. Ao mesmo tempo, sua escritura está profundamente ligada ao corpo, o que distingue seu corpo dos outros: "Olvido guaranis y castejanos, marafos afros duros brasileños porque sei que escribo y esto es como grafar impresso todo el contorno de un cuerpo vivo en el muro de la calle central" (Bueno, 1992, p. 32). A união entre sua escritura e a recuperação do corpo físico é particularmente 
reveladora, dadas as maneiras pelas quais seu corpo é usado em sua profissão de prostituta. $\mathrm{O}$ aspecto testemunhal do texto se conecta à oralidade, também explorada na obra de Ruffato (2009). Por último, é importante notar que a afirmação de si mesma é inseparável das sequências de memória, fornecendo aos leitores uma visão agonizante e subjetiva do mundo da protagonista.

Toda a obra é um exercício de lembrar a morte inconclusiva, com base em vários pontos de vista. Dessa forma, a memória oferece outro aspecto ao que Andreas Huyssen (2003) descreve como as tradições "mutiladas" do sujeito periférico, pois é proferida em uma língua que é uma fusão produtiva de múltiplas vozes, uma nova linguagem transnacional e desafiadora. Semelhante a outros experimentos multilíngues de autores como Junot Diaz e Cristina Garcia, Mar paraguayo exige do público leitor a aceitação de um certo nível de ambiguidade na linguagem, uma tarefa desafiante que requer que os leitores deduzam os diferentes significados da obra. Nesse caso, os falantes de português, espanhol, guarani ou, até mesmo, de todas as três línguas são obrigados a ler meticulosamente e referenciar o glossário. Devido a isso, o texto capta aspectos da incomunicabilidade do sujeito marginalizado de uma maneira que poucas obras logram, uma ideia que é notoriamente apresentada por Gaytri Spivak (1988) na sua teoria sobre a falta de voz do sujeito subalterno.

De fato, em seu comentário sobre Mar paraguayo e outras narrativas migratórias na literatura brasileira, Angélica Madeira argumenta que "as identidades que ali se representam são sempre precárias e deficientes" (Madeira, 2012, p. 55). Enquanto elas podem ser precárias, eu diria que Madeira estende demais seu argumento. Embora a expressão da voz e a recuperação do corpo possam ser fragmentadas, a linguagem que se apresenta em Mar paraguayo está longe de ser deficiente e poderia até ser vista como uma das principais forças da obra. O idioma traz à vida uma experiência complexa que não é nem facilmente capturada nem fácil de ler. Como Franconi argumenta, a inquietação do texto é possível graças a seus códigos e suas geografias que se cruzam, espelhando as formas pelas quais a protagonista vê e é vista no mundo: "Mar paraguayo potencializa variados modos de olhar e ser olhado através de uma complexa teia de insinuações, dissimulações, vaivéns, enfim, transversalidades várias, sendo, até onde sei, um texto 
inaugurador do cruzamento de falares fronteiriços poeticamente recriados e, por isso mesmo, inquietante" (Franconi, 2006, p. 112).

Semelhante ao texto de Ruffato (2009), o uso da linguagem em Mar Parguayo capta não só uma realidade espacial, mas também uma realidade temporal, estendendo a interseção de geografias. Embora a ação na história se desenrole na costa brasileira, a linguagem da marafona del balneário é elaborada a partir de vários tempos e espaços, revelando suas raízes. A linguagem desloca a atenção do leitor para a experiência espacial da protagonista. Em sua famosa deliberação sobre o desvio de tempo, Jorge Luis Borges (1947, p. 13), fazendo uma referência ao Heraclitus, escreve: "O tempo é um rio que me varre junto, mas eu sou o rio". Essa imagem, outra referência à água, baseia-se na fluidez e na idiossincrasia da passagem do tempo. Enquanto o tempo pode proporcionar a sensação de um movimento para a frente, os seres humanos estão presos em seu próprio paradigma temporal, com seus próprios ritmos internos e suas próprias cadências. Como o fluxo amorfo da água, sem começo e sem fim, a história da protagonista não tem um final claro.

O público leitor não verifica se marafona matou o "velho", nem há qualquer indício quanto ao que pode acontecer a seguir - pelo contrário, ela começa e termina sua narrativa com uma mera afirmação indenitária e espacial. Na primeira linha do romance, ela diz: "Yo soy la marafona del balneário. Acá, en Guaratuba, vivo de suerte" (Bueno, 1992, p. 15). Na sua última frase, ela fala: "Mi mar? Mi mar soy yo. Íyá" (Bueno, 1992, p. 73). O mar não é só uma metáfora do eu, mas, na verdade, é marafona, como vemos na sua declaração final. Esse eu pode ser fragmentado, periférico, desafiante ou confundido, mas declara sua presença inequivocamente.

\section{Conclusão}

Nas últimas décadas, pode-se notar um foco renovado na memória, no contexto da modernidade global, refletido na literatura contemporânea. Dá para perceber isso claramente no aumento do gênero testemunhal, cujos vestígios são vistos nas duas obras examinadas neste trabalho. $O$ foco renovado também indica uma tentativa de aproximar a subjetividade pessoal da memória. Andreas Huyssen argumenta que esse retorno à nossa memória coletiva na sociedade revela uma tentativa de "nos ancorar em um mundo 
caracterizado por uma instabilidade crescente do aumento do tempo e da fratura do espaço vivido" (Huyssen, 2003, p. 18). Em vez de simplesmente transladar as narrativas para outros espaços ou tempos, será que a memória é capaz de fixar essas obras em tempos e espaços mais históricos e estabelecidos? Ganham as narrativas uma sensação de aterramento em um mundo deslocalizado e desterritorializado? Eu respondo de forma afirmativa. Baseado em minhas leituras, essas narrativas permitem os protagonistas imigrantes a se anexar, embora provisoriamente, às raízes e aos vínculos mais profundos no terreno da memória, ajudando na experiência, muitas vezes, tumultuosa de deslocamento geográfico.

Acima de tudo, o que os textos relacionados à imigração revelam sobre as configurações espaçotemporais é que elas são múltiplas, móveis e diversas vezes contraditórias. A raça, a classe social, o gênero e o status no processo de migração influenciam a forma como o espaço e o tempo são experienciados, mostrando que as fronteiras e as distinções geográficas chegam a ser vagas, suavizadas, flexíveis ou ainda indiscerníveis. Frequentemente, o regional e o local são reproduzidos de forma multifacetada, transformando o "nacional" em um marcador menos relevante de identidade, do lugar físico e do tempo. Como dá para ver na experiência de Ruffato, a fabricação do "regional" põe em questão a sua própria existência, expondo-o como uma criação: "A ideia era essa mesmo, usar o regionalismo para questionar exatamente o que se exige questionar [...]. Uma radicalização de um lado exatamente pra discutir, na verdade, o que é o regionalismo, se é que ele existe" (Ruffato, 2013, informação verbal). O que é curioso sobre a atenção à origem geográfica dos imigrantes protagonistas é que suas memórias da "nação" permanecem com frequência em algum lugar entre a memória do que foi e a fantasia do que pode ser. Em contraste com essa falta de terra firme, a linguagem dos protagonistas imigrantes revela-se um marcador consistente de localidade e identidade levada para os espaços transnacionais.

\section{Referências}


ANDERMANN, Jens (2011). Abismos del tercer espacio: Mar paraguayo, portuñol salvaje y el fin de la utopía letrada. Revista Hispánica Moderna, v. 64, p. 11-24, jun.

SOUSÂNDRADE, Joaquim de Sousa (1979 [1871]). O guesa. São Luís: Sioge.

AUGÉ, Marc (1994). Não lugares: introdução a uma antropologia da supermodernidade. 4. ed. Tradução de Maria Lúcia Pereira. Campinas: Papirus.

BORGES, Jorge Luis (1947). Nueva refutación del tiempo. Buenos Aires: Oportet \& Haereses.

BRICKELL, Katherine; DATTA, Ayona (2011). Translocal geographies: spaces, places, connections. Farnham: Ashgate.

BUENO, Wilson (1992). Mar paraguayo. Curitiba: Secretaria de Estado da Cultura do Paraná.

BUARQUE, Chico (2003). Budapeste. São Paulo: Companhia das Letras.

CAMBACERES, Eugenio (1924 [1887]). En la sangre. Buenos Aires: Minerva.

CARVALHO, Bernardo (2009). O filho da mãe. São Paulo: Companhia das Letras.

CERTEAU, Michel de (1984). The practice of everyday life. Berkeley: University of California Press.

DELEUZE, Gilles; GUATTARI, Felix (1986). Kafka: toward a minor literature. Minneapolis: University of Minnesota Press.

FRANCONI, Rodolfo A. (2006) O olhar oblíquo: uma categoria cultural: conceituação e exemplos. Revista de Crítica Literaria Latinoamericana, v. 32, n. 63, p. 105-15.

FREITAG, Ulrike; VON OPPEN, Achim (2010). Translocality: the study of globalising processes from a southern perspective. Leiden: Brill.

GALERA, Daniel. Cordilheira (2008). São Paulo: Companhia das Letras.

GELMAN, Juan (1986). Composiciones. Barcelona: Edicions del Mall.

HATOUM, Milton. Relato de um certo Oriente (1990). São Paulo: Companhia das Letras.

HUYSSEN, Andreas (2003). Present pasts: urban palimpsests and the politics of memory. Stanford: Stanford University Press.

KAYGUSUZ, Sema (2013). A national literature. In: EDINBURGH WORLD WRITER'S CONFERENCE. Anais... Izmir, fev. 
KRAUSZ, Luis Sérigo (2011). Desterro: memórias em ruínas. São Paulo: Tordesilhas.

LESSER, Jeff (2013). Immigration, ethnicity, and national identity in Brazil, 1808 to the present. Cambridge: Cambridge University Press.

LEVY, Tatiana (2003). O silêncio da representação: uma leitura de Eles eram muitos cavalos. Estudos de Literatura Brasileira Contemporânea, n. 22, p. 173-184.

LISBOA, Adriana (2010). Azul-corvo. Rio de Janeiro: Rocco.

MADEIRA, Angélica (2012). Línguas na fronteira, línguas na diáspora. Humanidades, n. 59, p. 47-55.

MONTALDO, Graciela (2011). El mundo de la cultura. Revista Hispánica Moderna, v. 64, n. 1, p. 1-9.

NAKASATO, Oscar (2011). Nihonjin. São Paulo: Saraiva.

OAKES, Tim; SCHEIN, Louisa (2006). Translocal China: linkages, identities and the reimagining of space. London: Routledge.

PERLONGHER. Nestor (1992). Sopa paraguaia. In: BUENO, Wilson. Mar paraguayo. Curitiba: Secretaria de Estado da Cultura do Paraná.

SCOLLON, Ronald; SCOLLON, Suzanne B. K. (2003). Discourses in place: language in the material world. London: Routledge.

SPIVAK, Gayatri Chakravorty (1988). Can the subaltern speak? Basingstoke: Macmillan.

RODRIGUES, Marco Antonio (2012). Mobilidade precária em Terra estrangeira e em Estive em Lisboa e lembrei de você. Estudos de Literatura Brasileira Contemporânea, n. 39, p. 181-192.

RUFFATO, Luiz (2001). Eles eram muitos cavalos. São Paulo: Boitempo.

RUFFATO, Luiz (2005). Mamma, son tanto felice. Rio de Janeiro: Record. (Inferno provisório, v. 1.)

RUFFATO, Luiz (2009). Estive em Lisboa e lembrei de você. São Paulo: Companhia das Letras.

RUFFATO, Luiz. Entrevista concedida a Cecily Reynor. João Pessoa, 5 ago. 2013. Encontro pessoal.

TONUS, José Leonardo (2012). O imigrante na literatura brasileira: instrumentalização de uma figura literária. In: DALCASTAGNÈ, Regina; MATA, Anderson Luis Nunes da (Org.). Fora do retrato: estudos de literatura brasileira contemporânea. Vinhedo: Horizonte. 
VILLAÇA, Alcides (2009). Ruffato cria trama ágil com percepções vivas de Lisboa. Folha de S. Paulo, 17 out.

Recebido em agosto de 2014.

Aprovado em outubro de 2014.

\section{resumo/abstract}

\section{Linguagem, espaço e nação: um mapeamento das identidades multigeográficas do protagonista imigrante}

\section{Cecily Raynor}

Neste trabalho, analiso duas obras que narram a migração: Estive em Lisboa e lembrei de você (2009), de Luiz Ruffato, um romance contemporâneo centrado na história de um migrante mineiro que vai para Lisboa, e Mar paraguayo (1992), de Wilson Bueno, que conta a história de uma prostituta paraguaia sem nome que reside em Guaratuba. Mais especificamente, argumento que os romances de migração com temas contemporâneos desafiam, alongam e/ou interrompem a coesão narrativa do espaço-tempo, obscurecendo, muitas vezes de forma progressiva, as fronteiras entre o nacional e o transnacional. Examino a ideia do espaço tanto no sentido concreto, no âmbito doméstico e o espaço urbano, quanto no sentido metafórico. Dentro deste marco teórico expandido, estendo o argumento espacial ainda mais, postulando que essas narrativas não apenas transgridem ou transcendem os espaços tangíveis, mas também que geram novas ou alternativas possibilidades espaciais a partir das quais podemos observar a construção e manutenção da identidade.

Palavras-chave: migração, imigração, trans-nacionalidade, teoria espacial.

\section{Language, space and nation: a mapping of the multi-geographical identities of the immigrant protagonist}

Cecily Raynor

In this paper, I analyze works portraying migration: Estive em Lisboa e lembrei de você (2009), by Luiz Ruffatto, a work centered on the story of a Brazilian migrant to Lisbon, and Mar Paraguayo (1992 ), by Wilson Bueno, which recounts the tale of a Paraguayan prostitute living in Guaratuba. Specifically, I argue that contemporary migration- themed novels challenge, stretch and/or interrupt narrative time-space cohesion by obscuring, often gradually, the boundaries 
between the national and transnational. I examine space both in the concrete sense, in domestic and urban realms, as well as metaphorically. Within this expanded theoretical framework, I argue that these works not only test the idea of space, but also generate new or alternative spatial possibilities from which we can observe the construction and maintenance of identity.

Keywords: migration, immigration, transnationality, spatial theory. 